\title{
Perbandingan Obat Kumur Benzydamine Hydrochloride 22,5 mg dan Ketamin 40 mg dalam Mengurangi Nyeri Tenggorok dan Suara Serak Akibat Intubasi Endotrakeal
}

\author{
Teuku Andrian Firza, Nazaruddin Umar, Muhammad Ihsan \\ SMF Anestesiologi dan Terapi Intensif Fakultas Kedokteran Universitas Sumatera Utara/ \\ Rumah Sakit Umum Pusat H. Adam Malik Medan
}

\begin{abstract}
Abstrak
Nyeri tenggorok dan suara serak merupakan komplikasi yang sering muncul pada anestesi umum dengan intubasi endotrakeal yang memengaruhi kenyamanan dan kepuasan pasien setelah operasi. Penelitian ini bertujuan mengetahui efektivitas obat kumur benzydamine hydrochloride dan ketamin dalam mengurangi nyeri tenggorok dan suara serak setelah anestesi umum dengan intubasi endotrakeal. Terdapat 58 pasien berusia 16-60 tahun yang akan menjalani anestesi umum di Instalasi Bedah Sentral Rumah Sakit Umum Pusat H. Adam Malik Medan pada bulan Oktober-November 2013 dengan intubasi endotrakeal secara acak tersamar ganda dan dibagi dalam 2 kelompok yang sama besar. Sepuluh menit sebelum masuk kamar operasi, pasien menerima obat kumur ketamin atau benzydamine hydrochloride sebanyak $15 \mathrm{~mL}$ untuk dikumur selama 60 detik. Setelah operasi pasien diberikan ketorolak. Penilaian nyeri tenggorok dan suara serak dilakukan pada 1, 6, 12, dan 24 jam setelah selesai operasi. Hasil penelitian 6 pasien dikeluarkan dari penelitian. Insiden nyeri tenggorok pada jam I pada kelompok ketamin 14 dari 26 dan benzydamine hydrochloride 18 dari 26, sedangkan insidens suara serak pada jam I pada kelompok ketamin 16 dari 26 dan benzydamine hydrochloride 18 dari 26. Secara umum benzydamine hydrochloride lebih baik dibanding dengan ketamin, namun dengan uji chi-kuadrat tidak berbeda antara kedua kelompok obat.
\end{abstract}

Kata kunci: Benzydamine hydrochloride, intubasi endotrakeal, ketamin, nyeri tenggorok, suara serak

\section{Comparison of Benzydamine Hydrochloride $22.5 \mathrm{mg}$ and Ketamine $40 \mathrm{mg}$ Mouthwash Reduce Sore throat and Hoarseness after Endotracheal Intubation}

\begin{abstract}
Sore throat and hoarseness is a frequent complication in general anesthesia with endotracheal intubation, which affects the comfort and satisfaction of patients after surgery. This study aimed to determine the effectiveness of ketamine and benzydamine hydrochloride mouthwash in reducing sore throat and hoarseness following general anesthesia with endotracheal intubation. Fifty eight patients aged 16-60 years undergoing general anesthesia at the Central Operating Theater of H. Adam Malik General Hospital Medan with endotracheal intubation during October-November 2013 were double-blind randomized and divided equally into 2 groups. Ten minutes before entering the operating room, patients received ketamine or benzydamine hydrochloride mouthwash as much as $15 \mathrm{~mL}$ for a 60 seconds gargle. After surgery, patients were given ketorolac. Assessment on sore throat and hoarseness was performed at 1, 6, 12, 24 after the completion of surgery. Six patients were excluded from the study. The incidence of sore throat in the first hour in ketamine group was 14 of 26 and 18 of 26 in hydrochloride benzydamine group. Meanwhile, the incidence of hoarseness in the first hour for both groups were 16 of 26 and 18 of 26, respectively. In general, benzydamine hydrochloride is better than ketamine although the difference is not statistically significant.
\end{abstract}

Key words: Benzydamine hydrochloride, endotracheal intubation, ketamine, sore throat, hoarseness

Korespondensi: Teuku Andrian Firza, SMF Anestesiologi dan Terapi Intensif Fakultas Kedokteran Universitas Sumatera Utara/Rumah Sakit Umum Pusat H. Adam Malik Medan, Jl. Bunga Lau No. 17 Medan, Tlpn. 061-83621080, Mobile 082368687660,Email dr.t.andrianfirza@gmail.com 


\section{Pendahuluan}

Nyeri tenggorok dan suara serak merupakan komplikasi pascaoperasi yang dapat terjadi pada pasien yang menjalani operasi dengan anestesiumum dan intubasi pipa endotrakeal. ${ }^{1,2}$ Komplikasi tersebutakan pulih dalam waktu 72 jam dan bukan kegawatdaruratan serta tidak menyebabkan kecacatan, namun komplikasi ini dapat menyebabkan ketidakpuasan akibat ketidaknyamanan pasien pascaoperasi. ${ }^{2,5}$

Insidens nyeri tenggorok serta suara serak setelah intubasi pipa endotrakeal dari beberapa penelitian berbeda-beda, yaitu berkisar 14,4$100 \% .{ }^{5}$ Berbagai upaya telah dilakukan untuk mengurangi nyeri tenggorok dan suara serak pascaoperasi. Upaya nonfarmakologik antara lain adalah penggunaan pipa endotrakeal ukuran lebih kecil, lumbrikasi pipa endotrakeal dengan water-soluble jelly, instrumentasi jalan napas yang hati-hati, intubasi setelah relaksasi penuh, suctioning orofaring dengan hati-hati, meminimalkan tekanan intracuf dan ekstubasi apabila cuf pipa endotrakeal telah benar-benar kempes. ${ }^{6}$ Upaya farmakologik dapat berupa pemberian obat anestesi lokal seperti spray, obat kumur, atau tablet hisap yang diberikan sebelum atau setelah induksi. ${ }^{7}$

Beberapa obat terbukti dapat mengurangi insidens nyeri tenggorok dan juga suara serak akibat intubasi endotrakeal seperti ketamin dan benzydamine hydrochloride ( $\mathrm{HCl})$. Ketamin adalah obat anestesi intravena yang sudah lama digunakan dalam bidang anestesiologi. Data eksperimental menunjukkan bawa pemberian ketamin secara perifer memiliki efek analgetik dan juga anti-inflamasi dengan bekerja sebagai antagonis reseptor $N$-methyl-D-aspartat (NMDA) yang selain terdapat di sentral juga terdapat di perifer. Potensi analgetik dan antiinflamasi ketamin tersebut diharapkan dapat mencegah nyeri tenggorok akibat intubasi ETT bila diberikan ketamin kumur sebelumnya. Ketamin memiliki beberapa kelebihan seperti aman digunakan, efek samping yang minimal, ditoleransi dengan baik, dan tersedia di kamar operasi. $^{2}$

Benzydamine $\mathrm{HCl}$ merupakan obat antiinflamasi yang dipergunakan secara luas untuk pengobatan daerah mulut yang termasuk ke dalam golongan nonsteroid anti-inflamatory drug (NSAID) berbentuk topikal. Benzydamine $\mathrm{HCl}$ akan menghambat stimulasi TNF- $\alpha$ pada produksi prostaglandin $\mathrm{PGE}_{2}$ dan $\mathrm{PGI}_{2}$ dalam fibroblas ginggiva sehingga akan menghambat produksi prostaglandin secara tidak langsung.

Selain sebagai anti-inflamasi, benzydamine $\mathrm{HCl}$ juga mempunyai efek analgesia sebagai anestetik lokal yang tidak mengubah fungsi mukosa oral, bahkan dapat berperan sebagai protektor mukosa sehingga akan mengurangi nyeri tenggorok akibat kerusakan mukosa. ${ }^{8}$ Benzydamine $\mathrm{HCl}$ 0,15\% mengandung 22,5 mg benzydamine $\mathrm{HCl}$ dalam setiap $15 \mathrm{~mL}$ larutan. ${ }^{9}$

Penelitian sebelum ini membandingkan ketamin kumur $40 \mathrm{mg}$ dengan benzydamine $\mathrm{HCl}$ 0,075\% untuk mengurangi nyeri tenggorok pascaintubasi, didapatkan bahwa pemberian ketamin kumur $40 \mathrm{mg}$ saat 5 menit sebelum intubasi lebih berdayaguna dalam mengurangi nyeri tenggorok pascaanestesi umum dengan intubasi pipa endotrakeal dibanding dengan obat kumur benzydamine HCL 0,075\% yang dinilai pada saat sadar penuh dan 2 jam pascaekstubasi. ${ }^{16}$

Berdasarkan keunggulan dan kepraktisan benzydamine $\mathrm{HCl}$ dan ketamin pada uraian di atas, membuat peneliti ingin membandingkan antara pemberian obat kumur benzydamine $\mathrm{HCl} 22,5 \mathrm{mg}$ dan ketamin sebelum intubasi endotrakeal terhadap nyeri tenggorok dan suara serak pascaintubasi endotrakeal

Penelitian ini bertujuan membandingkan efektivitas obat kumur benzydamine $\mathrm{HCl}$ 22,5 mg dengan ketamin dalam mengurangi nyeri tenggorok dan suara serak akibat intubasi endotrakeal.

\section{Subjek dan Metode}

Penelitian ini dimulai setelah memperoleh izin Komite Etik Fakultas Kedokteran Universitas Sumatera Utara. Penelitian ini dilaksanakan di instalasi bedah sentral Rumah Sakit Umum Pusat H. Adam Malik Medan pada bulan Oktober hingga November 2013. Desain menggunakan uji klinis acak tersamar ganda. Sampel pada penelitian ini adalah pasien yang 
memenuhi kriteria inklusi.

Kriteria inklusi penelitian adalah pasien yang menjalani operasi elektif dengan anestesi umum intubasi endotrakeal, posisi operasi terlentang atau litotomy dengan posisi kepala tidak miring ke kiri atau kanan, usia 16-60 tahun, status fisik ASA 1-2, kelas Mallampati 1-2, lama operasi 60-120 menit. Pasien yang menyatakan bersedia untuk diikutsertakan dalam penelitian diharuskan mengisi lembar persetujuan dan memberikan tanda tangan pada lembar persetujuan tersebut.

Kriteria eksklusi adalah pasien dengan keluhan nyeri tenggorok dan juga suara serak saat sebelum operasi atau sedang mengalami infeksi jalan napas atas, riwayat hipersensitif terhadap ketamin dan atau benzydamine $\mathrm{HCl}$, operasi di daerah mulut, tenggorokan, leher, muka, bedah saraf, bedah toraks, riwayat operasi laring atau trakea, atau ada kelainan pada rongga mulut (orofaring, laring).

Kriteria drop out penelitian jika terjadi kesulitan intubasi ETT (lebih dari 2x upaha intubasi ETT), terjadi reaksi alergi terhadap obat anestesi, kumur (benzydamine $\mathrm{HCl}$ atau ketamin), terjadi komplikasi respirasi (seperti hipoksia) atau kardiovaskular (termasuk syok, aritmia, perdarahan) selama operasi, ETT mengalami kebocoran, keluar dari posisi atau tercabut, serta lama operasi kurang dari 1 jam atau lebih dari 2 jam.

Perkiraan besar sampel penelitian ini dihitung dengan menggunakan dua variabel independent (benzydamine $\mathrm{HCl}$ dan ketamin) yang tidak berpasangan. Skala pengukuran yang dipergunakan adalah skala katagorik yang mengandung nilai dikotomi (sembuh atau tidak sembuh) pada skala nominal dan informasi peringkat (ringan, sedang, berat) pada skala ordinal. Besarnya sampel ditujukan untuk menguji hipotesis terhadap 2 proporsi independent maka besar sampel dihitung berdasar atas rumus: ${ }^{11}$

$$
\begin{aligned}
& \mathrm{n}^{1}=\mathrm{n}^{2}
\end{aligned}
$$

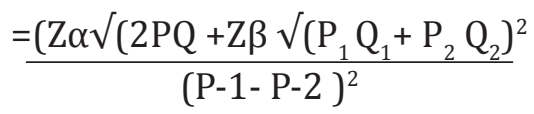

Setelah dihitung, besar kedua sampel untuk kedua kelompok adalah 58 orang terdiri atas
29 orang kelompok masing-masing.

Sepuluh menit sebelum pasien masuk ke kamar operasi, pasien tersebut mendapatkan obat kumur benzydamine $\mathrm{HCl}$ atau ketamin sebanyak $15 \mathrm{~mL}$ untuk dikumur selama 60 detik. Pasien diberikan premedikasi dengan midazolam 0,05 mg/kgBB dan fentanil 2 ug/kgBB, induksi dengan propofol 2-3 mg/ $\mathrm{kgBB}$ dan rokoronium $0,6 \mathrm{mg} / \mathrm{kgBB}$. Intubasi dilakukan dengan menggunakan ETT ukuran 7,0 untuk perempuan dan 7,5 untuk lakilaki. Pemeliharaan anestesi dengan $\mathrm{N}_{2} \mathrm{O}: \mathrm{O}_{2}$ $=2: 2$ dan isofluran. Setelah operasi pasien diberikan ketorolak. Penilaian nyeri tenggorok dan suara serak dilakukan pada 1, 6, 12, dan 24 jam setelah selesai operasi, dinilai oleh penilai yang tidak tahu obat kumur apa yang telah diberikan terhadap pasien.

Dilakukan pengamatan dan wawancara terhadap pasien tentang nyeri tenggorok dan suara serak yang dinilai menggunakan pain scale dengan nilai 0 sampai 3 . Derajat nyeri tenggorok pascaoperasi skor $0=$ tidak ada nyeri tenggorok (VAS 0), skor $1=$ nyeri tenggorok ringan adalah dijumpai nyeri tenggorok namun tidak nyeri pada saat menelan (VAS 1-3), Skor $2=$ nyeri tenggorok sedang adalah dijumpai nyeri tenggorok dan nyeri saat menelan (VAS 4-6), skor 3= nyeri tengorokan berat adalah dijumpai nyeri tenggorok disertai susah menelan (VAS 7-10). Sementara penilaian terhadap suara serak meliputi: nilai $0=$ tidak didapatkan suara serak, nilai $1=$ suara serak ringan hanya dirasakan oleh penderita, namun tidak terdengar oleh pemeriksa. Nilai $2=$ suara serak sedang dapat didengar oleh pemeriksa. Nilai 3= suara serak berat, yaitu afonia.

Data yang terkumpul diperiksa kembali kelengkapannya sebelum ditabulasi dan diolah kemudian dianalisis dengan program epi-info dan disajikan dalam bentuk tabel, kalimat, dan grafik. Data yang terkumpul ditabulasi ke dalam master tabel dengan menggunakan software microsoft office excel 2007. Data numerik ditampilkan dalam nilai rata-rata \pm standar deviasi, sedangkan data kategorik ditampilkan dalam jumlah (persentase).

Uji statistika dilakukan menggunakan uji chi-square dan uji-t. Batas kemaknaan yang 
ditetapkan 5\%. Interval kepercayaan yang dipakai 95\% dengan nilai $\mathrm{p}<0,05$ dianggap bermakna secara statistika.

\section{Hasil}

Dari 58 pasien, terdapat 6 pasien yang dikeluarkan dari penelitian, 3 pasien dari grup ketamin dan 3 pasien dari grup benzydamine $\mathrm{HCl}$. Pasien dikeluarkan karena lama operasi melebihi batas waktu yang telah ditentukan, yaitu 120 menit terhitung sejak mulai $\mathrm{N}_{2} \mathrm{O}$ dinaikkan hingga $\mathrm{N}_{2} \mathrm{O}$ dimatikan. Oleh karena itu, tercatat 52 pasien dalam penelitian ini. Karakteristik subjek tersebar pada kedua kelompok seperti terlihat pada Tabel 1.

Berdasar atas hasil uji chi-square dan uji-t menurut karakteristik jenis kelamin, usia, ASA, mallampati, lama operasi, ID ETT serta jenis operasi pada kedua kelompok secara statistik tidak berbeda bermakna $(\mathrm{p}>0,05)$.

Penilaian nyeri tenggorok akibat intubasi endotrakeal setelah pemberian obat kumur ketamin atau benzydamine $\mathrm{HCl}$ dilakukan sebanyak 4 kali, yaitu pada 1 jam, 6 jam, 12 jam dan 24 jam setelah operasi saat pasien masih berada di ruang pemulihan. Insidens nyeri tenggorok pada 1 dan 6 jam setelah operasi lebih rendah pada kelompok benzydamine $\mathrm{HCl}$ dibanding dengan kelompok ketamin,

Tabel 1 Karakteristik Umum Pasien

\begin{tabular}{|c|c|c|c|}
\hline Karakteristik & $\begin{array}{l}\text { Kelompok } \\
\text { Ketamin }\end{array}$ & $\begin{array}{c}\text { Kelompok } \\
\text { Benzydamine }\end{array}$ & Nilai p \\
\hline Jenis kelamin $\mathrm{n}$ & & & 0,358/chi-square \\
\hline Laki-laki & 6 & 9 & \\
\hline Perempuan & 20 & 17 & \\
\hline Usia (tahun *) & & & $0,1 / u j i-t$ \\
\hline Standar deviasi & 14,009 & 11,812 & \\
\hline Mean & 33,23 & 39 & \\
\hline ASA n : I & 17 & 15 & $0,569 /$ chi-square \\
\hline II & 9 & 11 & \\
\hline Mallampati : I & 25 & 25 & 1,0 /chi-square \\
\hline II & 1 & 1 & \\
\hline ID ETT $: 7,0$ & 20 & 17 & $0,358 /$ chi-square \\
\hline 7,5 & 6 & 9 & \\
\hline Lama operasi (mnt*) & & & $0,815 / u j i-t$ \\
\hline Standar deviasi & 14,951 & 14,544 & \\
\hline Mean & 108,46 & 108,46 & \\
\hline Jenis operasi: & & & 0,329 /chi-square \\
\hline B. digestif & 2 & 4 & \\
\hline B. onkologi & 3 & 5 & \\
\hline B. ortho (atas) & 5 & 8 & \\
\hline B. ortho (bawah) & 3 & 3 & \\
\hline B. urologi & 2 & 3 & \\
\hline B. plastik & 6 & 1 & \\
\hline Obgyn & 5 & 2 & \\
\hline
\end{tabular}

Keterangan: tabel disajikan dalam bentuk jumlah (\%) dan rata-rata (* mean) 
Tabel 2 Insidens Nyeri Tenggorok berdasarkan Pemberian Obat

\begin{tabular}{clcccc}
\hline Jam & \multicolumn{1}{c}{ Insidens } & Ketamin & Benzydamine & Total & Nilai p \\
\hline I & Tidak nyeri & 14 & 18 & 32 & Chi square \\
& Ringan & 9 & 6 & 15 & $0,522^{*}$ \\
& Sedang & 3 & 2 & 5 & \\
& Berat & 0 & 0 & 0 & \\
6 & Tidak nyeri & 12 & 17 & 29 & Chi-square \\
& Ringan & 12 & 8 & 20 & $0,369 *$ \\
& Sedang & 2 & 1 & 3 & \\
& Berat & 0 & 0 & 0 & \\
& Tidak nyeri & 17 & 23 & 40 & Chi-square \\
& Ringan & 8 & 3 & 11 & $0,124 *$ \\
& Sedang & 1 & 0 & 1 & \\
& Berat & 0 & 0 & 0 & Chi-square \\
Tidak nyeri & 24 & 23 & 47 & $0,638^{*}$ \\
& Ringan & 2 & 3 & 5 & \\
& Sedang & 0 & 0 & 0 & \\
& Berat & 0 & 0 & 0 & \\
\hline
\end{tabular}

Keterangan: * nilai $\mathrm{p}>0,05$ secara statistik berbeda tidak bermakna

baik insidenss nyeri tenggorok ringan, sedang, maupun tidak ada nyeri (Tabel 2).

Demikian juga data pada 12 dan 24 jam setelah operasi terjadi peningkatan perbaikan ataupun pemulihan insidens nyeri tenggorok dibanding dengan jam sebelumnya pada kedua kelompok. Terdapat perbedaan persentase, namun hasil uji chi-square didapatkan nilai $p>0,05$ berarti bahwa secara statistika tidak berbeda bermakna antara kedua kelompok obat terhadap nyeri tenggorok akibat intubasi endotrakeal pada jam pertama, ke-6, ke-12, dan ke-24 setelah operasi (Tabel 2).

Pengumpulan data suara serak pada 12 jam dan 24 jam setelah operasi juga dilakukan bersamaan dengan data nyeri tenggorok. Dari data dapat dilihat bahwa penilaian suara serak 1 jam, 6 jam, 12 jam, dan 24 jam baik pada kelompok ketamin maupun kelompok benzydamine $\mathrm{HCl}$ sebagian besar didapatkan suara serak dengan kategori ringan ( $p>0,05)$, dengan insidens yang makin berkurang pada pemeriksaan-pemeriksaan berikutnya (Tabel $3)$.
Pada kedua kelompok ditemukan 1 orang dari masing-masing kelompok dengan suara serak kategori berat yang ditemukan hanya pada pemeriksaan jam pertama ( $p>0,05$; Tabel $3)$.

Secara tradisional hasil uji klinis dilakukan uji hipotesis yang menghasilkan nilai $\mathrm{p}$, namun nilai p saja tidak banyak memberikan informasi manfaat terapi atau prosedur terapi. Hal yang lebih informatif adalah persentase terapi yang diuji memberi perbaikan dibanding dengan kontrol (menghitung relative risk reduction/ RRR), atau berapa beda proporsi kesembuhan atau kegagalan antara terapi eksperimental dan kontrol (absolut risk reduction/ARR). Number needed to treat/NNT, yaitu jumlah pasien yang diobati untuk mendapat tambahan 1 hasil yang baik atau menghindarkan 1 kegagalan. ${ }^{11}$ Pada penelitian ini ketamin sebagai kontrol.

Untuk nyeri tenggorok besarnya absolute risk reduction (ARR) dapat dihitung dengan pengurangan besarnya proporsi kegagalan pada kelompok kontrol (control event rate) CER) dalam hal ini adalah kelompok ketamin, 
Tabel 3 Insidens Suara Serak berdasarkan Pemberian Obat

\begin{tabular}{clcccc}
\hline Jam & \multicolumn{1}{c}{ Insidens } & Ketamin & Benzydamine & Total & Nilai p \\
\hline I & Tidak serak & 16 & 18 & 34 & Chi-square \\
& Ringan & 7 & 4 & 11 & $0,768^{*}$ \\
& Sedang & 2 & 3 & 5 & \\
\multirow{2}{*}{6} & Berat & 1 & 1 & 2 & \\
& Tidak serak & 13 & 20 & 33 & Chi-square \\
& Ringan & 10 & 5 & 15 & $0,214^{*}$ \\
& Sedang & 2 & 1 & 3 & \\
& Berat & 1 & 0 & 1 & \\
& Tidak serak & 18 & 22 & 40 & Chi-square \\
& Ringan & 7 & 3 & 10 & $0,368{ }^{*}$ \\
& Sedang & 1 & 1 & 2 & \\
& Berat & 0 & 0 & 0 & Chi-square \\
& Tidak serak & 24 & 24 & 48 & $1,0 *$ \\
& Ringan & 2 & 2 & 4 & \\
& Sedang & 0 & 0 & 0 & \\
& Berat & 0 & 0 & 0 & \\
\hline
\end{tabular}

Keterangan : * Nilai $\mathrm{p}>0,05$ secara statistik berbeda tidak bermakna

dengan proporsi kegagalan pada kelompok eksperimental (experimental event rate/EER) dalam hal ini adalah kelompok benzydamine hydrochloride. Besar CER yang didapatkan merupakan jumlah pasien yang mengalami nyeri tenggorok, pada kelompok ketamin adalah 12 dari 26. Sementara, besar EER yang didapat merupakan jumlah pasien yang mengalami nyeri tenggorok pada kelompok benzydamine $\mathrm{HCl}$ yaitu 8 dari 26. Besarnya ARR pada penelitian ini adalah $15,3 \%$. Hal ini berarti perbedaan keberhasilan obat kumur benzydamine $\mathrm{HCl}$ dalam mengurangi nyeri tenggorok pascaoperasi dibanding dengan kelompok kontrol (ketamin) sebesar 15,3\%.

Besarnya relative risk reduction (RRR) untuk nyeri tenggorok dapat dihitung dengan cara membagi hasil ARR dengan nilai pada CER. Berdasar atas perhitungan didapat hasil RRR adalah 33,1\% yang artinya obat kumur benzydamine $\mathrm{HCl}$ dapat menurunkan angka kegagalan 33,1\% dibanding dengan kontrol (ketamin). Besarnya number needed to treat (NNT) untuk nyeri tenggorok didapat dengan rumus 1/ARR dan hasilnya adalah sebesar 6,5 atau 7 pasien, artinya setiap kita mengobati 7 pasien dengan obat eksperimental akan memperoleh tambahan satu pasien yang sembuh atau menghindarkan satu pasien yang tidak sembuh. Nilai NNT yang semakin kecil berarti semakin baik, namun harus dipertimbangkan pula outcome yang dinilai (kematian atau urtikaria), efek samping obat, harga, ketersediaan, penerimaan pasien, dan karakteristik klinis lain yang relevan. ${ }^{11}$

\section{Pembahasan}

Nyeri tenggorok dan suara serakakibat intubasi endotrakeal dapat disebabkan oleh trauma pada laring, faring, trakea. Hal tersebut dapat merupakan akibat tindakan laringoskopi, insersi pipa endotrakeal, ataupun keduanya.

Karakteristik subjek penelitian berdasar atas jenis kelamin, usia, ASA, mallampati, lama operasi tidak dijumpai perbedaan bermakna antara kedua kelompok. Dengan demikian, kedua kelompok homogen dan layak untuk dibandingkan.

Mallampati pada penelitian ini dikontrol 
pada mallampati 1 dan 2 , artinya tidak dijumpai kesulitan berarti dalam melakukan tindakan intubasi pipa endotrakeal. Pada pasien dengan kesulitan intubasi, penatalaksanaan jalan napas menjadi lebih sulit sehingga lebih mudah terjadi cidera jalan napas yang menyebabkan nyeri tenggorok pascaintubasi., ${ }^{3,12}$ Demikian pula dengan ASA pasien dibatasi dengan ASA 1 dan 2. Insidens nyeri tenggorok dan suara serak berdasar atas mallampati dan ASA selanjutnya tidak dianalisis lebih lanjut pada penelitian ini. Usia subjek penelitian dibatasi pada usia 16-60 tahun. Walaupun pada penelitian yang dilakukan oleh Ahmed dkk. ${ }^{12}$ didapat insidens nyeri tenggorok tidak berbeda bermakna pada usia 18-60 tahun, insidens nyeri tenggorok lebih sering ditemukan pada usia lebih dari 60 tahun. Insidens nyeri tenggorok berdasarkan kelompok usia selanjutnya juga tidak dianalisis lebih lanjut pada penelitian ini.

Lamaoperasipadapenelitian iniadalah pada rentang 60-120 menit dengan lama operasi rata-rata 108,46 menit pada kedua kelompok obat. Walaupun penelitian yang dilakukan oleh Christensen dkk. ${ }^{14}$ didapat bahwa nyeri tenggorok setelah operasi tidak berhubungan dengan lama operasi yang berkisar 20-480 menit, namun dari penelitian yang dilakukan oleh Novia ${ }^{8}$ di RSUP Cipto Mangunkusumo Jakarta didapatkan bahwa lama operasi lebih dari 2 jam setelah operasi merupakan salah satu faktor yang memengaruhi insidens nyeri tenggorok pascaoperasi. ${ }^{8}$

Tujuan pemberian obat kumur adalah sebagai analgesia pre-emtif. Konsep analgesia pre-emtifadalah pemberian analgesik sebelum terjadi input nosiseptik sehingga mencegah sensitasi (blok reseptor, peningkatan ambang nosiseptif) dengan hasil akhir mencegah nyeri pascabedah.

Dari data jam I dapat dilihat insidens nyeri tenggorok ringan pada kelompok ketamin sebesar 9 dari 26 pasien dan benzydamine $\mathrm{HCl}$ sebesar 6 dari 26 pasien. Nyeri sedang pada kelompok ketamin sebesar 3 dari 26 pasien dan benzydamine $\mathrm{HCl}$ sebesar 2 dari 26 pasien. Pasien yang tidak mengalami nyeri tenggorok pada kelompok ketamin sebesar 14 dari 26 pasien dan benzydamine $\mathrm{HCl}$ sebesar 18 dari
26 pasien. Kedua kelompok memiliki insidens tidak mengalami nyeri tenggorok lebih dari setengahnya maka dapat disimpulkan bahwa pemberian obat kumur benzydamine $\mathrm{HCl}$ dan ketamin efektif mengurangi nyeri tenggorok setelah operasi.

Selama 24 jam periode evaluasi, insidens nyeri tenggorok tertinggi terjadi pada 6 jam setelah operasi. Terjadi kenaikan insidens nyeri tenggorok ringan dan sedang pada kedua kelompok dibanding dengan 1 jam, namun ada perbaikan dibanding dengan $12 \mathrm{jam}$ dan $24 \mathrm{jam}$ setelah operasi. Pada kedua kelompok tidak terjadi nyeri tenggorok berat. Nyeri tenggorok dapat terjadi akibat lesi yang terjadi, yaitu abrasi fokal, perdarahan, granuloma, ulkus, laserasi laring biasanya jarang terjadi. Lesi laring paling sering terjadi di daerah posterior subglotis. Perdarahan dan reaksi radang dapat dideteksi 3 jam pascaekstubasi. ${ }^{9,10}$ Penyebab lain mungkin tersamar setelah pemberian analgetik setelah anestesi umum sehingga nyeri tenggorok kurang dirasakan oleh pasien pada pemeriksaan jam pertama. Hal lain juga disebabkan oleh konsentrasi plasma tertinggi pada pemberian benzydamine $\mathrm{HCl} 100 \mathrm{mg}$ adalah $37 \mathrm{ng} / \mathrm{mL}$ yang terjadi 3 jam setelah pemberian $^{15}$ sehingga pada pemeriksaan 1 jam setelah operasi insidens pasien yang tidak mengalami nyeri tenggorok tinggi, namun peningkatan insidens pada 6 jam setelah operasi karena konsentrasi benzydamin $\mathrm{HCl}$ tidak berada pada konsentrasi tertinggi.

Benzydamine $\mathrm{HCl}$ memiliki efek analgesik, anti-inflamasi, antipiretik, anestesi lokal, dan juga antibakterial. Pada pemberian sistemik maupun topikal, benzydamine $\mathrm{HCl}$ akan berada dalam konsentrasi yang tinggi di jaringan yang mengalami inflamasi, sedangkan pada jaringan yang normal terdapat dalam konsentrasi yang sangat rendah. Dengan demikian, pemberian topikal akan meningkatkan efektivitasnya. ${ }^{15}$

Nilai ARR pada penelitian ini adalah 15,3\% yang berarti bahwa perbedaan keberhasilan benzydamine $\mathrm{HCl}$ mengurangi nyeri tenggorok pascaoperasi dibanding dengan kelompok ketamin sebesar 15,3\%. Sementara nilai RRR untuk nyeri tenggorok adalah $33,1 \%$, artinya benzydamine $\mathrm{HCl}$ dapat menurunkan angka 
kegagalan 33,1\% dibanding dengan ketamin. Hasil penelitian ini menunjukkan bahwa pemberian benzydamine $\mathrm{HCl} 22,5 \mathrm{mg}$ saat 10 menit sebelum intubasi dapat menurunkan insidens nyeri tenggorok pascaoperasi. Secara statistik $(p>0,05)$ memang menunjukkan tidak bermakna antara kedua kelompok. Namun, jika ditelusuri lebih lanjut, pemberian benzydamine $\mathrm{HCl}$ yang diberikan sebelum terjadi simulus nosiseptif akan memblok stimulus nosiseptif selama dan juga pascapemasangan ETT. Hal tersebut akan mengakibatkan proses modulasi nyeri di kornu dorsalis terhambat sehingga analgesia yang terjadi akan dimulai sebelum terjadi kerusakan jaringan dan tetap bertahan selama/sesudah operasi bila analgetik selama /sesudah operasi cukup baik. Hal ini terbukti dari tingginya persentase pasien yang tidak mengalami nyeri tenggorok pada jam pertama pemeriksaan. Waktu paruh benzydamine $\mathrm{HCl}$ pada pemberian oral, intravena maupun kumur adalah 9,4 $\pm 2,9$ jam sehingga efek pemberian obat ini masih dapat terlihat sampai 24 jam. $^{18}$

Pada penelitian sebelumnya yang dilakukan oleh Subekti ${ }^{16}$ dengan membandingkan daya guna obat ketamin kumur $40 \mathrm{mg}$ dengan benzydamine $\mathrm{HCl}$ 0,075\% untuk mengurangi nyeri tenggorok pascaintubasi ternyata obat ketamin kumur $40 \mathrm{mg} 5$ menit sebelum intubasi lebih berdayaguna dalam mengurangi nyeri tenggorok pasca-anestesi umum dengan pipa endotrakeal dibanding dengan obat kumur benzydamine HCL 0,075\% pada saat sadar penuh dan 2 jam pascaekstubasi. ${ }^{16}$ Penilaian ketamin lebih berdayaguna dibanding dengan benzydamine $\mathrm{HCl}$ disebabkan oleh jarak waktu yang singkat antara waktu berkumur dan dilakukan tindakan intubasi, yaitu 5 menit. Obat kumur benzydamine $\mathrm{HCl}$ sebagai antiinflamasi yang memiliki aktivitas analgetik dan dekongestan yang cepat, efek analgetik tersebut terjadi 10 menit setelah pemberian. ${ }^{15}$ Penyebab kedua adalah konsentrasi obat kumur benzydamine $\mathrm{HCl}$ yang diberikan adalah $0,075 \% \quad(22,5 \mathrm{mg}$ dalam $30 \mathrm{~mL}$ diencerkan dengan $\mathrm{NaCl}$ 0,9\%), sementara penggunaannya tanpa diencerkan, berkumur sebanyak $15 \mathrm{~mL}$ selama 60 detik. Oleh karena itu, agar tidak mengurangi efektivitas kerja benzydamine $\mathrm{HCl}$ maka konsentrasi obat yang dipakai pada penelitian ini adalah $0,15 \%$ atau 22,5 mg dalam $15 \mathrm{~mL}$.

Pada pemantauan jam I didapatkan pasien yang tidak mengalami suara serak pada kelompok benzydamine $\mathrm{HCl}$ sebanyak 18 dari 26 dan ketamin sebanyak 16 dari 26. Kedua kelompok memiliki insidens tidak mengalami nyeri tenggorok lebih dari separuh sampel sehingga dapat disimpulkan bahwa pemberian obat kumur benzydamine $\mathrm{HCl}$ dan juga ketamin efektif mengurangi suara serak pascaintubasi. Hal ini disebabkan oleh kontak obat kumur dengan mukosa di daerah oral, hipofaring, serta nasofaring. Penyerapan melalui mukosa umumnya efisien karena epidermidis stratum korneum yang merupakan hambatan utama penyerapan obat di kulit tidak ditemukan di mukosa. Mukosa kaya akan pembuluh darah sehingga cepat masuk dalam sirkulasi darah. ${ }^{16}$ Terdapat suplai darah yang banyak pada mukosa oral yang didapatkan dari arteri yang berjalan paralel ke permukaan submukosa. ${ }^{17}$ Peningkatan insidens suara serak tejadi pada pemeriksaan jam ke-6 tetapi menurun pada pemeriksaan berikutnya. Sama halnya seperti pada nyeri tenggorok, hal tersebut disebabkan oleh reaksi radang yang dapat dideteksi 3 jam pascaekstubasi. ${ }^{9,10}$ Penyebab lain karena konsentrasi benzydamine $\mathrm{HCl}$ tidak berada pada konsentrasi tertinggi.

Penyebab suara serak pascaintubasi antara lain perdarahan submukosa, ulkus karena kontak dengan kaf yang lama, edema subglotik, dan laringitis. Pipa nasogastrik dapat juga mengakibatkan terjadi suara serak yang diduga karena gangguan pada cabang posterior saraf rekuren laring. ${ }^{9,10}$ Pencegahan penting selain pemberian obat kumur sebelum dilakukan intubasi adalah menjaga tekanan intrakaf. Oleh karena itu, pemberian tekanan intrakaf 20-30 $\mathrm{cmH}_{2} \mathrm{O}$ efektif menurunkan insidens suara serak karena pada tekanan kurang dari $30 \mathrm{cmH}_{2} \mathrm{O}$ tidak terjadi gangguan aliran darah kapiler sehingga tidak merusak mukosa jalan napas. ${ }^{2}$

Insidens nyeri tenggorok dan suara serak pada kedua kelompok mengalami penurunan selama 24 jam. Hal tersebut dapat dilihat dari 
insidens nyeri tenggorok dan suara serak yang sangat rendah pada 24 jam pascaoperasi.

Proses penyembuhan terjadi dengan cepat disebabkan suplai darah yang banyak pada mukosa oral yang didapat dari arteri yang berjalan paralel ke permukaan submukosa. Tidak seperti pada pembuluh darah di kulit, mukosa pada daerah oral kekurangan arterio venous, tetapi mempunyai anastomosis yang banyak dari arteriol dan kapiler. Kondisi ini menyebabkan proses penyembuhan jaringan di mukosa oral lebih cepat daripada di kulit. ${ }^{17}$

Nilai ARR untuk suara serak adalah sebesar $7,7 \%$, berarti bahwa perbedaan keberhasilan benzydamine $\mathrm{HCl}$ dalam mengurangi kejadian suara serak pascaoperasi dibanding dengan kelompok ketamin sebesar 7,7\%. Besarnya RRR adalah 20,1\%, yang berarti obat kumur benzydamine $\mathrm{HCl}$ dapat menurunkan angka kegagalan 20,1\% dibanding dengan ketamin.

Benzydamine $\mathrm{HCl}$ merupakan anti-inflamasi yang digunakan secara luas untuk pengobatan daerah mulut dan termasuk golongan NSAID secara topikal. Benzydamine menunjukkan pengaruh menghambat efek stimulasi TNF- $\alpha$ pada produksi prostaglandin $\mathrm{PGE}_{2}$ dan $\mathrm{PGI}_{2}$ dalam fibroblas ginggiva manusia sehingga benzydamine $\mathrm{HCl}$ akan menghambat produksi prostaglandin secara tidak langsung. Selain sebagai anti-inflamasi, benzydamine $\mathrm{HCl}$ juga mempunyai efek analgesi, lokal anestesi yang tidak mengubah fungsi mukosa oral dan lebih lanjut benzydamine berperan sebagai proteksi mukosa untuk mengurangi morbiditas nyeri tenggorok karena kerusakan mukosa. ${ }^{15}$

Ketamin akan berinteraksi dengan reseptor NMDA. Ketamin bekerja dengan mengurangi aktivitas TNF kappa $\mathrm{B}$, mengurangi produksi TNF-alpha serta mengurangi sintesis nitric oxide sehingga pada pemberian secara perifer antagonis reseptor NMDA seperti ketamin memiliki efek analgetik serta anti-inflamasi. Dengan potensi ini, pemberian ketamin secara topikal dengan cara berkumur saat sebelum intubasi endotrakeal dapat mencegah nyeri tenggorok. 2,18,19

Walaupun secara persentase insidens nyeri tenggorok dan suara serak pada kelompok benzydamine $\mathrm{HCl}$ lebih baik dibanding dengan ketamin, namun secara statistika dengan uji chi-square didapatkan nilai $\mathrm{p}>0,05$ yang berarti penggunaan benzydamine $\mathrm{HCl}$ maupun ketamin tidak terdapat perbedaan bermakna dalam mengurangi insidens nyeri tenggorok dan suara serak setelah intubasi endotrakeal.

Penelitian ini dilakukan dengan jumlah sampel yang tidak besar sehingga hasil akhir pada penelitian ini tidak bermakna pada kedua obat. Perlu dilakukan penelitian lebih lanjut menggunakan sampel yang lebih besar dalam upaya lebih mempresentasikan populasi.

\section{Simpulan}

Pemberian obat kumur benzydamine $\mathrm{HCl}$ dan ketamin secara pre-emtif sama-sama efektif mengurangi insidens nyeri tenggorok dan suara serak akibat intubasi endotrakeal.

Pada tindakan anestesi intubasi endotrakeal disarankan penggunaan obat kumur ketamin $40 \mathrm{mg}$ dalam $15 \mathrm{~mL} \mathrm{NaCl} 0,9 \%$ ataupun benzydamine $\mathrm{HCl} 15 \mathrm{~mL}$ untuk mencegah nyeri tenggorok dan suara serak.

\section{Daftar Pustaka}

1. Oatway M, Reid A, Sawynox J. Peripheral antihyperalgesic actions of ketamin and amitriptyline in a model of mild thermal injury in the rat. Anesth Analg. 2003;97:168-73 .

2. Adnyana IN. Efek pemberian obat kumur ketamin sebelum pemasangan pipa endotrakeal untuk mengurangi nyeri tenggorok pascaoperasi. Jakarta: Bagian Anestesiologi dan Terapi Intensif Fakultas Kedokteran Universitas Indonesia-RSUPN Cipto Mangunkusumo; 2008.

3. Ogata J, Minami K, Horishita T, Shiraishi M, Okamoto T, Terada T, dkk. Gargling with sodium azulene sulfonat reduces the post operative sore throat after intubation of the trachea. Anesth Analg. 2005; 101:2903.

4. Ayoub C, Ghobashy A, Koch M, McGrimley L, Pascale, Qadir S, dkk. Widespread application of topical steriods to decrease sore throat hoarness and cough after 
tracheal intubation. Anesth Analg. 1998;87:714-6.

5. Higgins PP, Chung F, Mezei G. Postoperative sore throat after ambulatory surgery. $\mathrm{Br} \mathrm{J}$ Anaest. 2002;88(4):582-4.

6. Canbay O, Celebi N, Sahin A, Celiker V, Ozgen S, Aypar U. Ketamin gargle for attenuating post operative sore throat. $\mathrm{Br}$ J Anaesth. 2008;100(4):490-3.

7. Yarlitasari D. Perbandingan pengaruh penggunaan pelincir jeli lidokain 2\% dengan salin $0.9 \%$ terhahap keberhasilan pemasangan LM proseal dan kekerapan "sore throat" pasca anestesi inhalasi dengan $\mathrm{N}_{2} \mathrm{O} / \mathrm{O}_{2} /$ enfluran. Jakarta: Bagian Anestesiologi dan Terapi Intensif Fakultas Kedokteran Universitas Indonesia - RSU Cipto Mangunkusumo; 2006.

8. Novia R. Insidens nyeri tenggorok dan suara serak pasca anestesi umum dengan tekhnik intubasi di RSCM. Jakarta: Departemen Anestesiologi Fakultas Kedokteran Universitas Indonesia; 2006.

9. Handoko. Hubungan antara ukuran pipa trakea dengan nyeri tenggorok dan suara serak pasca anestesia. Jakarta: Fakultas Pascasarjana Universitas Indonesia; 1990.

10. Morgan GE. Airway management. Dalam: Morgan GE, Mikhail MS, Murray MJ, penyunting. Clinical anesthesiology. Edisi ke-4. Los Angeles: McGraw-Hill; 2006. hlm. 91-116.

11. Sastroasmoro S, Ismael S. Dasar-dasar metodologi penelitian. Edisi ke-3. Jakarta: Sagung Seto; 2008.

12. Ahmed A, Abbasi S, Ghafoor HB, Ishaq M. Postoperative sore throat after selctive surgical procedures. J Ayub Med Coll Abbottabad. 2007;19(2)12-4.
13. Kati I, Tekin M, Silay E, Huseynoglu UA, Yildiz H. Does benzydamine hydrochloride applied preemtively reduce sore throat due to laryngeal mask airway. Anesth Analg. 2004;99;710-2.

14. Christensen AM, Willemoes LH, Lundby L, Jacobsen KB. Post operative throat complaints intubation. Br J Anaesth. 1994; 73:786-7.

15. Supriatin. Pemberian tablet hisap Benzidamine hydrochloride sebelum pemasangan laryngeal mask airway proseal (LMP) untuk mengurangi nyeri tenggorok pascaoperasi. Jakarta: Bagian Anestesiologi dan Terapi Intensif Fakultas Kedokteran Universitas Indonesia-RSUPN Cipto Mangunkusumo; 2007.

16. Subekti BE. Perbandingan daya guna obat ketamin kumur $40 \mathrm{mg}$ dan benzydamine $\mathrm{HCl} \quad 0,075 \%$ untuk mengurangi nyeri tenggorok postintubasi. Yogyakarta: Universitas Gadjah Mada; 2012.

17. Squiver CA, Finkelstein MW. Oral mukosa. Dalam: Nancy S, penyunting. Ten cate's oral histology development strukture and function. Edisi ke-6. Missouri: Mosby; 2003. hlm. 329-75.

18. Kulsum. Perbandingan keberhasilan obat kumur ketamin dengan obat kumur aspirin dalam mengurangi nyeri tenggorok dan suara serak setelah operasi endotrakeal. Medan: Departemen/SMF Anestesiologi dan Terapi Intensif Fakultas Kedokteran Universitas Sumatera Utara/RSUP Haji Adam Malik; 2011.

19. Trevor AJ, White PF. General anesthetics. Dalam: Katzug BG, penyunting. Basic \& clinical pharmacology. Edisi ke-9. Boston: Mc Graw-Hill; 2004. hlm. 401-7. 